\title{
Erikoiskasvit kevätvehnän esikasveina
}

Marjo Keskitalo, Kaija Hakala, Lauri Jauhiainen, Hannu Känkänen

MTT Kasvintuotannon tutkimus, 31600 Jokioinen, marjo.keskitalo@mtt.fi

\section{Tiivistelmä}

Yleinen maatalouspolitiikka CAP muuttuu ja uusia ohjeistuksia ryhdytään soveltamaan vuoden 2013 jälkeen. Uudistus tuo mukanaan ympäristötukien viherryttämisen, jolla tarkoitetaan ilmaston ja ympäristön kannalta suotuisten viljelytoimenpiteiden noudattamista. Viherryttämisellä tarkoitetaan pysyvien nurmien säilyttämistä, vähintään kolmen viljelykasvin viljelyä sekä luonnonhoitoisten alojen kuten kesantojen lisäämistä

Vuonna 2009 alkaneessa MTT:n tutkimuksessa "Monipuolisella kasvilajistolla satoa ja kestävyyttä - MONISOPU" selvitetään kasvintuotannon monipuolistamista malliviljelykiertojen avulla. Nykyisessä tilanteessa oleellista on löytää viljelyjärjestelmiä, jotka tuovat apua kasvintuotannon ongelmakohtiin kuten panosriippuvuuteen (keinolannoitteet, kasvinsuojeluaineet, energian käyttö), ympäristön kestävyyteen (ravinteiden huuhtoutuminen, biodiversiteetti) sekä tuotannon kannattavuuteen ja joita tuleva CAP-uudistus voisi tukea. Tutkimuskasviksi valittiin kevätvehnä, jonka viljelyn ennustetaan lisääntyvän ilmaston lämmetessä ja joka jo nyt edustaa kasvina Etelä-Suomea, jossa tuotannon yksipuolistuminen on edennyt pisimmälle. Esikasveiksi valittiin seitsemän vaihtoehtoa (härkäpapu, kaura, kevätrypsi, kevätvehnä, lupiini, tattari, öljyhamppu ja öljypellava), joiden merkitystä kevätvehnän tuotannossa tutkitaan. Vielä meneillään olevien kahden kenttäkokeen tuloksia tullaan hyödyntämään suunniteltaessa kevätvehnän kiertoja erityyppisten viljelykasvien kanssa.

Tulokset esikasvien vaikutuksesta kahden kokeen välillä erosivat selvästi. Ensimmäisessä vain härkäpapu kevätvehnän esikasvina paransi satoa verrattuna tilanteeseen, jossa vehnän esikasvina oli kevätvehnä. Muut esikasvit alensivat kevätvehnän satomääriä vaikkakaan erot eivät olleet tilastollisesti merkitseviä. Toisen kokeen tulokset olivat lähes päinvastaisia, sillä kevätvehnään verrattuna kaikkien muiden esikasvien jälkeen kevätvehnän sadot olivat merkitsevästi suuremmat. Esikasvien paremmuus vehnäsatojen kohottajina oli seuraava: härkäpapu $(+810 \mathrm{~kg} / \mathrm{ha})$, kevätrypsi $(+784 \mathrm{~kg} / \mathrm{ha})$, kaura $(+562 \mathrm{~kg} / \mathrm{ha})$, öljyhamppu $(+426 \mathrm{~kg} / \mathrm{ha})$, tattari $(+416 \mathrm{~kg} / \mathrm{ha})$ ja öljypellava (+349 kg/ha).

Johtopäätöksenä voidaan todeta, että esikasvit voivat hyvinä vuosina lisätä hehtaarikohtaisia vehnäsatoja 340 - 800 kilolla, kun taas joinakin vuosina esikasveista ei ole apua tai vaikutus voi olla mahdollisesti haitallinen. Näyttää myös siltä, että hehtaarisatojen nostoon riittää jo yksi erikoiskasvivuosi (ml. kaura) kevätvehnäviljelyn välissä.

Tutkimustulokset herättävät lukuisia jatkokysymyksiä siitä, miksi esikasvit vaikuttivat kahdessa kokeessa näinkin eri tavalla ja mistä sekä edulliset että mahdolliset haitalliset vaikutukset johtuvat. Kiinnostavaa on myös nähdä, kuinka monta vuotta esikasvin viljelyn jälkeen vaikutus on vehnäsadossa havaittavissa. Näitä tekijöitä tullaan jatkossa selvittämään MTT:n meneillään olevissa kenttäkokeissa sekä valmistuvien kasvusto- ja maanäyteanalyysien avulla.

Asiasanat esikasvi, viljelykierto, cap-uudistus, viljelyn monipuolistaminen, härkäpapu, kaura, kevätrypsi, kevätvehnä, lupiini, tattari, öljyhamppu, öljypellava, sato 


\section{Johdanto}

Yleinen maatalouspolitiikka muuttuu ja uusia ohjeistuksia ryhdytään soveltamaan vuoden 2013 jälkeen. Yksityiskohtia todennäköisesti hiotaan vielä, mutta pääpiirteissään CAP uudistus tuo mukanaan ympäristötukien viherryttämisen, jolla tarkoitetaan ilmaston ja ympäristön kannalta suotuisten viljelytoimenpiteiden noudattamista. Ohjeistuksia noudattaville tiloille ehdotetaan hehtaarikohtaista lisätukea. Viherryttämisellä tarkoitetaan pysyvien nurmien säilyttämistä, vähintään kolmen viljelykasvin viljelyä sekä luonnonhoitoisten alojen kuten kesantojen lisäämistä (MEMO/11/685).

Uusi tukimuoto muistuttaa nykyistä, ympäristötuen lisätoimenpiteenä olevaa viljelyn monipuolistamista, jonka on voinut A- tai B- alueella sijaitseva tila valita vuodesta 2007 lähtien. Perusperiaatteena on, että peltoalasta on oltava vähintään $10 \%$ nurmilla ja tilan on viljeltävä vähintään kolmea viljelykasvia, joista yhden on oltava muu kuin vilja ja joista yksi voi olla vähimmäisvaatimuksena ollut nurmi. Vuonna 2007 tuen valitsi vajaat 3000 viljelijää jotka samalla sitouttivat tilansa tuen piiriin seuraavaksi viisivuotiskaudeksi. Tuen valinneiden tilojen osuus tukien piiriin kuuluvista tiloista vaihtelee 5 - 14 \% välillä riippuen ELY-keskuksesta (TIKE 2011).

Tulevan CAP-uudistuksen viherryttämistoimenpiteeseen on syytä varautua, sillä nykyisestä vapaaehtoisuudesta poiketen se on suunniteltu pakolliseksi. Toisaalta, riippumatta CAP-uudistuksesta ilmastonmuutos tulee ravistamaan kasvintuotantoa tavalla, jonka lopullista vaikuttavuutta on vaikea ennustaa sateiden ja ääri-ilmiöiden vaihtelevuuden takia. Tuottajahintojen nopeiden muutosten takia myös tuotannon kannattavuuden suunnittelu on käynyt yhä vaikeammaksi. Perustellusti voidaan sanoa, että kasvintuotanto on viljelyhistoriamme suurimpien haasteiden kynnyksellä, joista selviytyäksemme tähän asti hyväksi koettujakin tuotantosysteemejä tulee tarkastella uudelleen. Lähes 100 vuotta kestäneen maatalouden erikoistumistaipaleen sijaan on aktiivisesti luotava menetelmiä, joiden avulla tilat ja maaseudun elinkeinorakenne monipuolistuvat. Kasvintuotannossa viljelyn monipuolistamista tulee ryhtyä tarkastelemaan siitä näkökulmasta, miten monipuolistaminen vahvistaa tilan joustoa vastaanottaa muuttuvia tuotanto-oloja sekä mitkä ja miten tuotettuina uudet viljelykasvit ja lajikkeet parhaiten palvelevat tiloja. Nyt jos koskaan monipuolistamista kannattaa tarkastella pitkällä aikajaksolla, sillä epävarmoissa tuotanto-oloissa mikään muu ei ole varmaa kuin muutos itsessään.

Vuonna 2009 alkaneessa MTT:n tutkimuksessa "Monipuolisella kasvilajistolla satoa ja kestävyyttä - MONISOPU" selvitetään kasvintuotannon monipuolistamista malliviljelykiertojen avulla. Kuvat 1-3 esittävät monipuolistamisen tapoja, mutta niiden taustaolettamukset ja tavoitteet eroavat. Nykyisessä tilanteessa oleellista on löytää viljelyjärjestelmiä, jotka tuovat apua kasvintuotannon ongelmakohtiin kuten panosriippuvuuteen (keinolannoitteet, kasvinsuojeluaineet, energian käyttö), ympäristön kestävyyteen (ravinteiden huuhtoutuminen, biodiversiteetti) sekä tuotannon kannattavuuteen ja joihin liittyvää monipuolistamista tuleva CAP-uudistus voisi tukea.

MTT:n tutkimuksissa lähestymistavaksi valittiin kuvan kolme kaltainen tilanne, jossa hypoteesina on että viljelykierrot parantavat viljelymaan kuntoa samalla kun tila itse monipuolistuu. Tutkimuskasviksi valittiin kevätvehnä, jonka viljelyn ennustetaan lisääntyvän ilmaston lämmetessä ja joka jo nyt edustaa kasvina Etelä-Suomea, jossa tuotannon yksipuolistuminen on edennyt pisimmälle. Esikasveiksi valittiin seitsemän vaihtoehtoa (härkäpapu, kaura, kevätrypsi, kevätvehnä, lupiini, tattari, öljyhamppu ja öljypellava), joiden merkitystä kevätvehnän tuotannossa tutkitaan. Vielä meneillään olevien kenttäkokeiden tuloksia tullaan hyödyntämään suunniteltaessa kevätvehnän kiertoja erityyppisten viljelykasvien kanssa. 


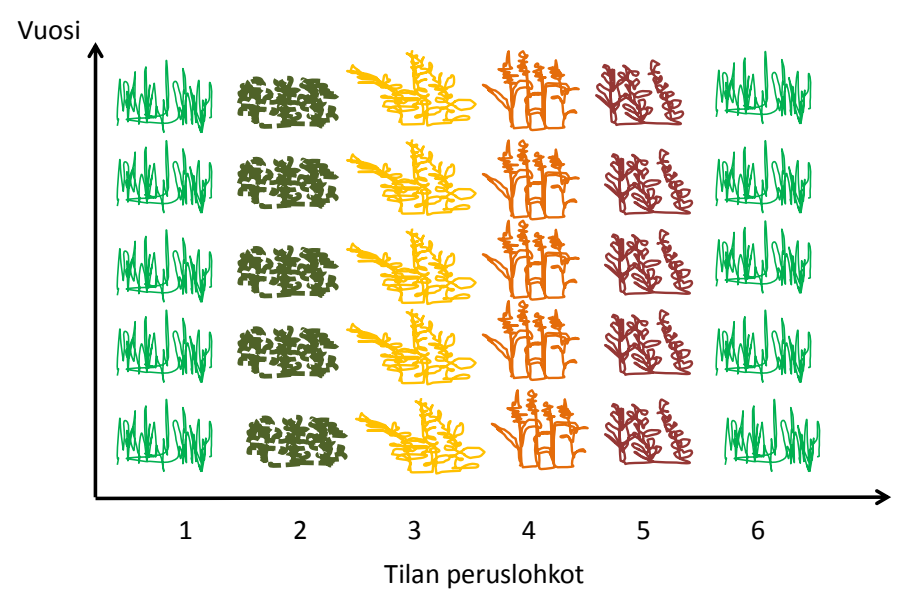

Kuva 1. Tilalla viljellään vuosittain monipuolisesti erityyppisiä viljelykasveja ja mahdollisen uhan sattuessa epäonnistuminen koskettaa vain osaa tilan kasveja. Lohkoilla viljely on yksipuolista eikä viljelykierron hyötyjä saavuteta. Kierto on hypoteettinen ja voi edustaa puhdas- tai sekakasvustoja.

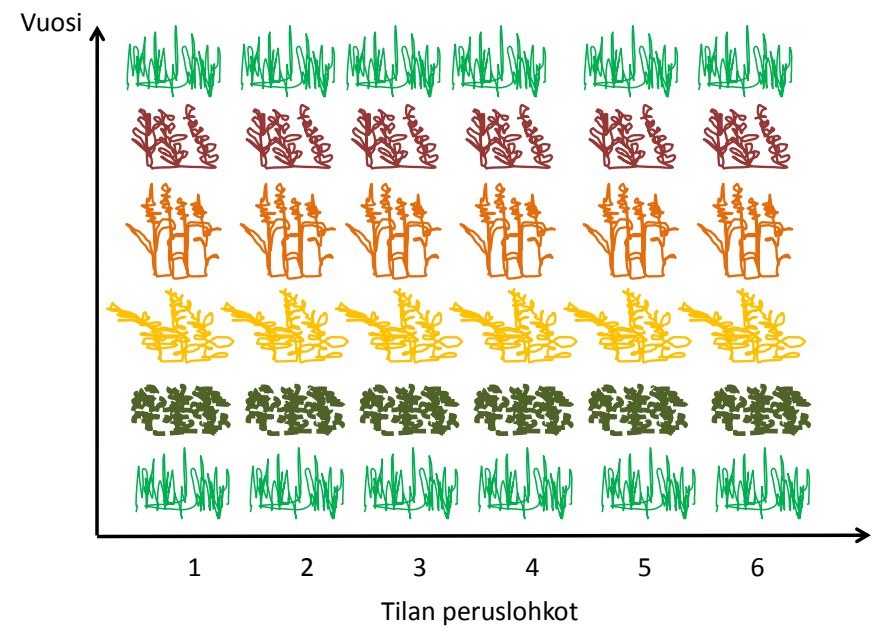

Kuva 2. Keskittyminen vuosittain yhteen viljelykasviin yksinkertaistaa työtehtäviä, mutta mahdollisen uhan sattuessa epäonnistuminen kohdistuu yhteen kasviin ja lisää suuren epäonnistumisen vaaraa. Lohkoilla toteutettavat viljelykierrot mahdollistavat monipuolisuudesta koituvien hyötyjen saamisen. 


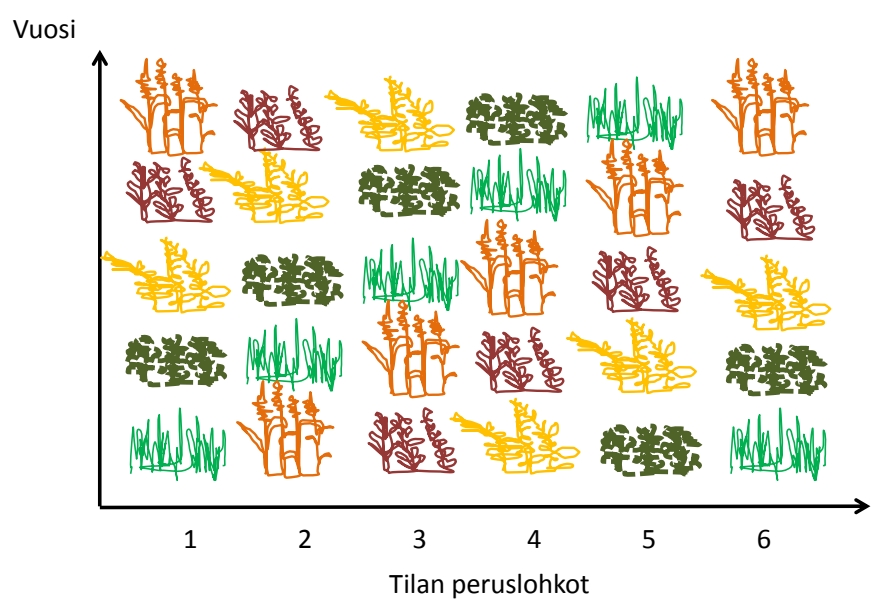

Kuva 3. Tilalla viljellään vuosittain monipuolisesti erityyppisiä viljelykasveja ja mahdollisen uhan sattuessa epäonnistuminen koskettaa vain osaa tilan kasveja. Lohkoilla toteutettavat viljelykierrot mahdollistavat monipuolisuudesta koituvien hyötyjen saamisen.

\section{Aineisto ja menetelmät}

Kevätvehnän esikasvitutkimusta varten perustettiin Jokioisiin kaksi lohkoittain satunnaistettua kenttäkoetta (kokeet 819 ja 820) savespitoisille maalajeille. Ennen perustamista kenttä oli syksyllä kynnetty, mutta seuraavina vuosina kentät lautasäestettiin syksyisin. Esikasvien jälkivaikutusta tutkittiin Kruunu-kevätvehnän avulla.

Ensimmäisenä koevuotena esikasvit kylvettiin 4-6 m x 10 m suuruisille ruuduille kahdessa tai kolmessa vaiheessa touko-kesäkuussa kasvin vaatimusten mukaisesti. Ensin kylvettiin viljat ja palkokasvit (Kontu-härkäpapu, Roope-kaura, Kruunu-kevätvehnä, Ludic-valkolupiini koe 819 tai Boruta-sinilupiini koe 820), sen jälkeen öljykasvit (Apollo-kevätrypsi, Finola-öljyhamppu, Heljäöljypellava) ja viimeisenä kesäkuun alussa tattari (Keskisen kanta). Kylvösiemenmäärinä käytettiin kunkin kasvilajin ohjeenmukaista määrää. Kevätlannoituksen yhteydessä typpeä eri kasvilajit saivat 40 $\mathrm{kg} / \mathrm{ha}$ (palkokasvit, tattari), $60 \mathrm{~kg} / \mathrm{ha}$ (öljyhamppu, öljypellava) tai $100 \mathrm{~kg} / \mathrm{ha}$ (viljat ja kevätrypsi). Mahdollinen kemiallinen rikkakasvien ja tuholaisten torjunta suoritettiin kunkin kasvilajin tarpeen mukaan.

Esikasvien jälkeen samalle kentälle kylvettiin suorakylvönä toukokuussa vuosina 2010 (koe 819) ja 2011 (koe 820) pelkästään kevätvehnää (Kruunu) ja lannoituksena annettiin $90 \mathrm{~kg} \mathrm{~N} / \mathrm{ha}$. Vehnän rikkakasvien torjuntaruiskutukset suoritettiin kesäkuussa. Kasvustoja havainnoitiin silmämääräisesti (mm. kehitysvaiheiden havainnointi) sekä otettiin kasvusto- ja maanäytteitä.

\section{Tulokset ja tulosten tarkastelu}

Vuonna 2009 perustetussa esikasvikokeessa (koe 819) valkolupiini- sekä härkäpapukasvustot jäivät tavanomaista harvemmiksi. Lisäksi valkolupiini jouduttiin korjaamaan tuoreena, sillä se ei ennättänyt tuleentua syksyllä. Vuonna 2010 perustetussa esikasvikokeessa (koe 820) sinilupiini jäi kuivuuden takia tavanomaista matalammaksi. Muut kuin lupiinikasvustot kehittyivät ja tuleentuivat normaaliin tapaan ja joista korjatut sadot voidaan olettaa olevan vertailukelpoisia kasvilajien yleiseen tasoon, mikä vielä varmistetaan punnittujen satotulosten avulla. Kevätvehnät taimettuivat ja kehittyivät silmämääräisesti tasaisesti. Kasvuston tuleennuttua koeruudut puitiin ja ruutusadon perusteella laskettiin hehtaarisadot, jotka on esitetty Taulukossa 1.

Kahden kokeen kevätvehnän satotulokset eroavat selvästi. Ensimmäisessä kokeessa (koe 819) vain härkäpapu kevätvehnän esikasvina paransi satoa verrattuna tilanteeseen, jossa vehnän esikasvina oli kevätvehnä. Sen sijaan muut kasvit alensivat kevätvehnän satoja, mutta vain valkolupiinin kohdalla vaikutus oli 10 prosentin riskitasolla merkitsevä. Sen sijaan koe 820 tuotti lähes päinvastaisen 
tuloksen, sillä kevätvehnään verrattuna kaikkien muiden esikasvien jälkeen kevätvehnän sadot olivat merkitsevästi suuremmat. Heikoimmillaankin kevätvehnän satoero jatkuvaan kevätvehnän viljelyyn oli lähes $350 \mathrm{~kg} / \mathrm{ha}$ (öljypellava) ja parhaimmillaan $810 \mathrm{~kg} / \mathrm{ha}$ (härkäpapu).

Taulukko 1. Esikasvien vaikutus kevätvehnän satoon (kg/ha) kahden MTT Jokioisissa sijaitsevan kenttäkokeen perusteella.

\begin{tabular}{|c|c|c|c|c|}
\hline & $\begin{array}{l}\text { Kevätvel } \\
\text { (Koe } 819\end{array}$ & sato v. 2010 & $\begin{array}{l}\text { Kevätveh } \\
\text { (Koe 820) }\end{array}$ & sato v. 2011 \\
\hline $\begin{array}{l}\text { Esikasvit } \\
\text { (v. } 2009 \text { koe 819; } \\
\text { v. } 2010 \text { koe } 820 \text { ) }\end{array}$ & Kg/ha (* & $\begin{array}{l}\text { Ero kg/ha, kun } \\
\text { esikasvina oli } \\
\text { kevätvehnä }\end{array}$ & Kg/ha (* & $\begin{array}{l}\text { Ero kg/ha, kun } \\
\text { esikasvina oli } \\
\text { kevätvehnä }\end{array}$ \\
\hline Härkäpapu & 3551 & $+73,0$ & $4002 * * *$ & $+810,0$ \\
\hline Kaura & 3385 & $-93,7$ & $3753 * *$ & $+561,5$ \\
\hline Kevätrypsi & 3270 & $-208,0$ & $3976^{* * *}$ & $+784,0$ \\
\hline Kevätvehnä & 3478 & & 3192 & \\
\hline Tattari & 3347 & $-132,0$ & $3608 * *$ & $+416,2$ \\
\hline Valko-/sinilupiini & $3135^{\circ}$ & $-343,0$ & 3936 *** & $+744,0$ \\
\hline Öljyhamppu & 3369 & $-110,0$ & $3617 * *$ & $+425,5$ \\
\hline Öljypellava & 3383 & $-95,4$ & $3541 *$ & $+349,3$ \\
\hline s.e & 179,2 & & 117,1 & \\
\hline $\mathbf{P}$ & $\mathbf{0 , 5 3}$ & & $<0,001$ & \\
\hline LSD & 370 & & 313 & \\
\hline
\end{tabular}

$\mathrm{o} / *)$ Merkityt esikasvit paransivat kevätvehnän satoa tilastollisesti merkitsevästi verrattuna tilanteeseen, jossa kevätvehnän esikasvina oli kevätvehnä: ***(P<0,001), **(P<0,01), *(P<0,05) ja $\mathrm{o}(\mathrm{P}<0,10)$

Australialaiset tutkijat keräsivät eri puolilla maailmaa tehtyjen syysvehnän esikasvikokeiden tuloksia ja arvioivat niiden perusteella esikasvien satovaikutuksen olevan syysvehnälle $470 \mathrm{~kg} / \mathrm{ha}$ (kaura) - $850 \mathrm{~kg} / \mathrm{ha}$ (canola ja öljypellava) - $1110 \mathrm{~kg} / \mathrm{ha}$ (herne) - $1800 \mathrm{~kg} / \mathrm{ha}$ (lupiini) luokkaa (Angus et al. 2008). Pohjois-Dakotassa (USA) verrattiin kahden matriisikokeen avulla 10 erikoiskasvin esikasvivaikutusta ensin toisiinsa ja kolmantena vuotena kevätvehnään. Tulosten perusteella löytyi parisenkymmentä sellaista esikasviyhdistelmää sadasta mahdollisesta, joissa kolmantena vuotena korjatun vehnäsadon määrä oli korkeampi i kuin monokulttuurimaisesti viljellyn vehnän sato (Krupinsky et al. 2006). Pohjoismaissa tehtyjen tutkimusten perusteella rypsin/rapsin, palkokasvien ja muiden erikoiskasvien tuoma sadonlisä kevätvehnälle on ollut yleensä alle $950 \mathrm{~kg} / \mathrm{ha}$ (Lindén 2008).

\section{Johtopäätökset}

Tulosten perusteella esikasvin merkitys vehnän katkaisukasvina voi vaihdella. Hyvinä vuosina erikoiskasvit esikasvina voivat lisätä vehnäsatoja 340 - $800 \mathrm{~kg} / \mathrm{ha}$, kun taas joinakin vuosina esikasveilla voi olla mahdollisesti haitallinen vaikutus. Joka tapauksessa vain esikasvien satoa kohottava vaikutus oli tilastollisesti merkitsevä, kun taas sadon alennukset valkolupiinia lukuun ottamatta sisältyivät luontaiseen vaihteluun. Näyttää myös siltä, että vehnän hehtaarisatojen nostoon riittää jo yksi erikoiskasvivuosi (ml. kaura) kevätvehnäviljelyn välissä.

Tutkimustulokset herättävät lukuisia jatkokysymyksiä siitä, miksi esikasvit vaikuttivat kahdessa kokeessa näinkin eri tavalla ja mistä sekä edulliset että mahdolliset haitalliset vaikutukset johtuvat. Kiinnostavaa on myös nähdä, kuinka monta vuotta esikasvin viljelyn jälkeen vaikutus on vehnäsadossa havaittavissa. Näitä tekijöitä tullaan jatkossa selvittämään MTT:n meneillään olevissa kenttäkokeissa sekä valmistuvien kasvusto- ja maanäyteanalyysien avulla. 


\section{Kirjallisuus}

Angus, J., Peoples, M., Kirkegaard, J., Ryan, M.H., \& Ohlander, L. 2008. The value of break crops for wheat. Global Issues Paddock Action. Proceedings of the 14th Australian Agronomy Conference. September 2008, Adelaide South Australia.

Krupinsky, J.M., Tanaka, D.L., Merrill, S.D., Liebig, M.A., \& Hanson, J.D. 2006.

Crop sequence effects of 10 crops in the northern Great Plains Agricultural Systems 88 (2006) 227-254.

Lindén, B. 2008. Efterverkan av olika förfrukter: inverkan på stråsädesgrödors avkastning och kvävetillgång en literaturöversikt. Rapport 14, 66 s. SLU, Skara, Sverige. http://pub.epsilon.slu.se/3288/1/porapp14.pdf

MEMO/11/685 Date: 12/10/2011. Yhteisen maatalouspolitiikan (YMP) uudistus pääpiirteissään. http://europa.eu/rapid/pressReleasesAction.do?reference $=$ MEMO/11/685\&format=HTML\&aged $=0 \&$ language $=$ fi $\&$ guiLanguage $=$ en

TIKE 2011. Maa- ja metsätalousministeriön tietopalvelukeskus.. 